WiESŁAWA GIERAŃCZYK

Jagiellonian College, Toruń, Poland

\title{
Economic Situation in the Manufacturing Sector as an Example of Modern Research in Industrial Geography in Poland
}

\begin{abstract}
The article presents change in the object of study of the industrial geography in Poland that took place in the late twentieth century with a context in the internal and external conditions of the functioning of the industrial activities. A kind of barometer of the impact of internal and external conditions for the functioning of industrial units and the scale of regional integration in this area can be achieved by studying the economic situation also known as business tendency. In this paper the author would like to draw attention to the economic condition survey in industry conducted by the Central Statistics Office (GUS) as an example of modern research in the industrial geography in Poland.
\end{abstract}

Key words: economic situation; industrial geography; manufacturing sector

\section{INTRODUCTION}

The industrial geography is a discipline which is particularly interested in the analysis of changes in the factors and the formation of the spatial structure of industry and businesses of all sizes, as well as forms of spatial concentration (groups, centres, districts, complexes) and scattered industry (Zioło, Borowiec, Kilar, 2007). The research range formulated in this way has been the subject to constant evolution, as with the developments in the organisation of the socio-economic space the scope of the discipline is also constantly changing. While once it was an industrial plant, later a company, an industrial system and a production chain, nowadays we talk about the global economic networks and, consequently, the new forms of spatial organisation of industry (Stryjakiewicz, 2010). At the same time the difficulty in determining the basic object of research is increasing. This is because industry is this sector of the economy, in which the boundaries between large part of industrial activities and services are under the influence of technological progress (especially the new ICT) and other factors (Stryjakiewicz, 2010). This makes the attention of researchers focused on the functional and holistic approach to economic and geographical phenomena, and problems of the old industrial geography (in accordance with the global trend) blend into the study of the overall economic geography. Changes taking place today on the study of industrial geography 
were considered by e.g. Zioło (1988, 2001, 2008a, 2008b), Stryjakiewicz (1994), Gierańczyk (2008a, 2008b), Czapliński (2008) and Rachwał (2008, 2010a), and the theoretical dimension of these changes in the industrial geography as a scientific discipline was the subject of discussion of e.g. Stryjakiewicz $(2002,2010)$ and Zioło (2006a).

Taking into account the specific research problems, it is noted that a fundamental change in the object of study of the industrial geography in Poland took place in the late twentieth century, with a change in the internal and external conditions of the functioning of the industrial activities described by e.g. T. Rachwał (2008). Going from a redistributive economic system to an economy based on free market mechanisms was a prerequisite for making a number of studies on the wider structural changes in Polish industry in the process of adaptation to the new economic conditions. The themes undertaken in this field were both those showing the general mechanisms of changes in the environment of the Polish industrial enterprises (e.g. Brocka-Palacz, 1990; Zioło, 1994, 2003, 2006a, 2013b; Stryjakiewicz, 1999; Wieloński, 1998; Rochnowski, 2000; Luchter, 2002; Domański, Stryjakiewicz, 2003; Gierańczyk, Stańczyk, 2003; Tobolska, 2004, 2006; Wieloński, Bazydło, 2003; Domański et al., 2005; Domański, 2006; Wieloński, 2006; Rachwał, Wiedermann, Kilar, 2009; Rachwał, 2010b, 2011a, 2011b, 2011c, 2012; Gierańczyk, Rachwał, 2012), as well as their impact on industrial structures (Rydz, Jażewicz, 1994; Paszkowski, 1996; Zioło, 1997, 2004, 2008a, 2008b; Kłysik, 1998; Mikołajkiewicz, 2001; Misztal, 2000, 2003; Rydz, Barańska, 2000; Czapliński, 2000, 2008, 2011, 2013; Rachwał 2002a, 2002b; Rydz, Jażewicz, 2002; Bazydło, Smętkowski, Wieloński, 2002; Czepczyński, 2002; Gierańczyk, Stańczyk, 2002; Musielak, 2002; Domański, 2003a; Makieła, 2003; Rydz, Szymańska, 2003; Fedan, 2006; Tkocz, 2006; Czapliński, Rachwał, Wiedermann, 2008; Wiedermann, 2008; Smętkowski, 2008; Niemczak, 2008; Wieloński, 2009; Kurek, 2009; Tkocz, Heder, 2012; Domański et al., 2013; Mrozińska, 2013), even though, as pointed out by M. Tkocz (2001), the geographical research on the restructuring processes in Poland had no theoretical or methodological basis.

Gradually, the phenomena stimulated by external circumstances have become the subject of research of industrial geographers: domestic (e.g. the formation of special economic zones: Bazydło, Smętkowski, Wieloński, 2002; Domański, Gwosdz, 2005a, 2005b; Domański, Gwosdz, Huculak, Wiedermann, 2005; Smętkowski, 2008; Wiedermann, Trojak, 2009; Kitowski, 2010, 2011, 2012) and international, including especially the increased globalisation and regionalisation processes (e.g. Makieła, 2002; Zioło, 2003; Tkocz, 2003; Sala, 2006; Huculak, 2006; Tobolska, Matykowski, 2006; Gierańczyk, 2008a, 2008b; Niemczak, 2009; Czapliński, Stawarska, 2010).

The resulting adjustments were analysed, among others, through the prism of concentration and integration of the world industrial companies, both in Poland and regional systems (e.g. Zioło, 2000, 2002, 2006b, 2009a; Domański, 2003c, 2005; Kilar, Cieluch, 2008; Sala, 2003, 2006; Tobolska, 2004; Śleszyński, 2010; Brezdeń, Spallek, 2013). The studied themes included manifestations of globalisation expressed in volume, directions and motives of: foreign investments in the Polish industry and in selected regions and sectors (e.g. Piasecka, 2001; Domański, 2000, 2001a, 2003b, 2003c, 2003d, 2004; Czepczyński, 2001; Tkocz, Sobala, 2006; Huculak, 2008); relocation processes (e.g. Domański, 2001b; 
Gwosdz, Domański, 2008; Gierańczyk, 2008a, 2008b); the role of industry in the development of the information society and the knowledge economy (e.g. Domański, 2000, 2003b; Zioło, 2009b, 2013a; Gierańczyk, 2009; Hryniewicz, 2013; Rachwał, 2013; Brzozowski, 2013); as well as innovation in industry (e.g Wieloński, Szmigiel, 2006; Bal-Woźniak, 2009; Borowiec, Dorocki, Jenner, 2009; Gierańczyk, 2010a, 2010b, 2010c; Gierańczyk, Rachwał, 2010; Gierańczyk, Kordowska, 2013, 2014; Szymańska, 2012; Rachwał, 2012) and various aspects of its competitiveness and determinants of development (e.g. Kwiatek-Sołtys, 2000; Wdowicka, 2002; May, 2002; Czapliński, 2003; Szmytkowska, 2004; Rachwał, 2005; Komornicki, 2006; Domański et al., 2011; Jaworski, 2006; Szmielińska-Pietraszek, Szymańska, 2008; Raczyk, Dobrowolska-Kaniewska, 2009; Dorocki, Borowiec, Boguś, 2013; Świdurska, 2009, 2010b, 2010c, 2012; Wiedermann, 2010; Gurbała, 2010). A kind of barometer of the impact of internal and external conditions for the functioning of industrial units and the scale of regional integration in this area can be achieved by studying the economic situation also known as business tendency.

Studies of economic situation are often the subject of research and analysis of economists. They are carried out in Poland by several institutions and research centres, also on a sectoral basis. The most common method of research is an economic condition survey. The survey is an opinion poll which is carried out among businesses or households to determine both current and future market trends. Due to the timeliness, regularity (every month and/or every three months) and universalism (virtually unchanged questionnaires of the economic situation survey are used in various sectors ${ }^{7}$, the results of these studies may be an interesting secondary data source, complementary for the current basic studies conducted by industrial geographers. An additional research context is a qualitative nature of the data. Methodology of the economic situation research conducted using the economic condition survey consists of gathering the opinions of entrepreneurs about the current and future situation of their enterprises in terms of elements such as backlog, production, financial situation, employment, prices, investment activity and encountered barriers. When responding to the economic condition survey, the respondents should base on their overall feelings about the current situation of the company and the expected capabilities of its development, without reference to the accounting records (Badanie..., 2011). Thus, the qualitative study of the economic situation conducted by cyclical economic condition survey may be an additional element for a more complete assessment of the economy and its various branches.

In this paper the author would like to draw attention to the economic condition survey in industry conducted by the Central Statistics Office (GUS) ${ }^{8}$. The results for Poland have been available since 1992 and for the voivodeships since 2011. This system presents simple and composite indicators of the economic condition of enterprises. Simple economic indicators include the economic balance. It is calculated as the difference between the percentage share of positive responses $(+)$ and negative responses $(-)^{9}$ to questions about current and expected

\footnotetext{
7 A detailed scope of the subject and object of the research was described in Badanie..., 2011.

8 They are harmonised with the studies of the economic situation survey and consumers in the EU.

9 The calculation of the simple index does not consider neutral answers.
} 
situation of the company. The value of the balance is in the range from -100 (if all respondents chose the adverse option from their point of view) to +100 (when all have chosen a positive variant). The index value $>0$ indicates a good business climate, while $<0$ - bad climate. Indicators for the entire industrial processing are calculated by weighing the answers to the questions according to the scheme set out in Figure 1.

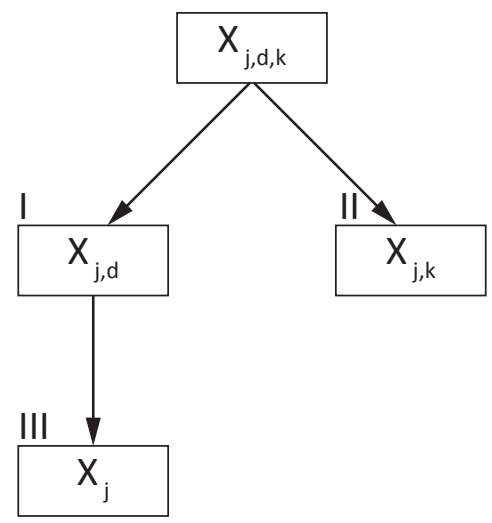

Fig. 1. The scheme of construction indicators for the general economic condition

Note: $\mathbf{X}_{\mathbf{j}} \mathbf{d}, \mathbf{k}$ is the index value of the economic condition calculated for the question $\mathbf{j}$, for the grouping $\mathbf{d}$ in accordance with the PKD, e.g. the branch of industry and class size $\mathbf{k}$

Source: Badanie koniunktury gospodarczej, 2011. Warszawa: GUS, Departament Przedsiębiorstw, 25

The initially performed analyses indicate that the monthly information on the economic balances could provide an interesting material for the study of regional diversity of opinion of industrial entrepreneurs on the condition of their businesses. Differentiation is visible both in terms of opinion about the current situation (A) as well as the predicted situation of businesses (B) (see Fig. 2).

There are also differences in the opinions of the surveyed components with relation to time (see Fig. 3).

Economic situation balances also allow capturing the correlations (see Tab. 1) and their changes over time between the assessments of components of the economic condition invoivodeships. For example, in December 2013, in the evaluation of manufacturing enterprises by the entrepreneurs in voivodeships, a strong positive correlation occurred between the current portfolio of all orders (Q2) and current production $(\mathrm{Q} 4 ; \mathrm{r}=0.803)$. 

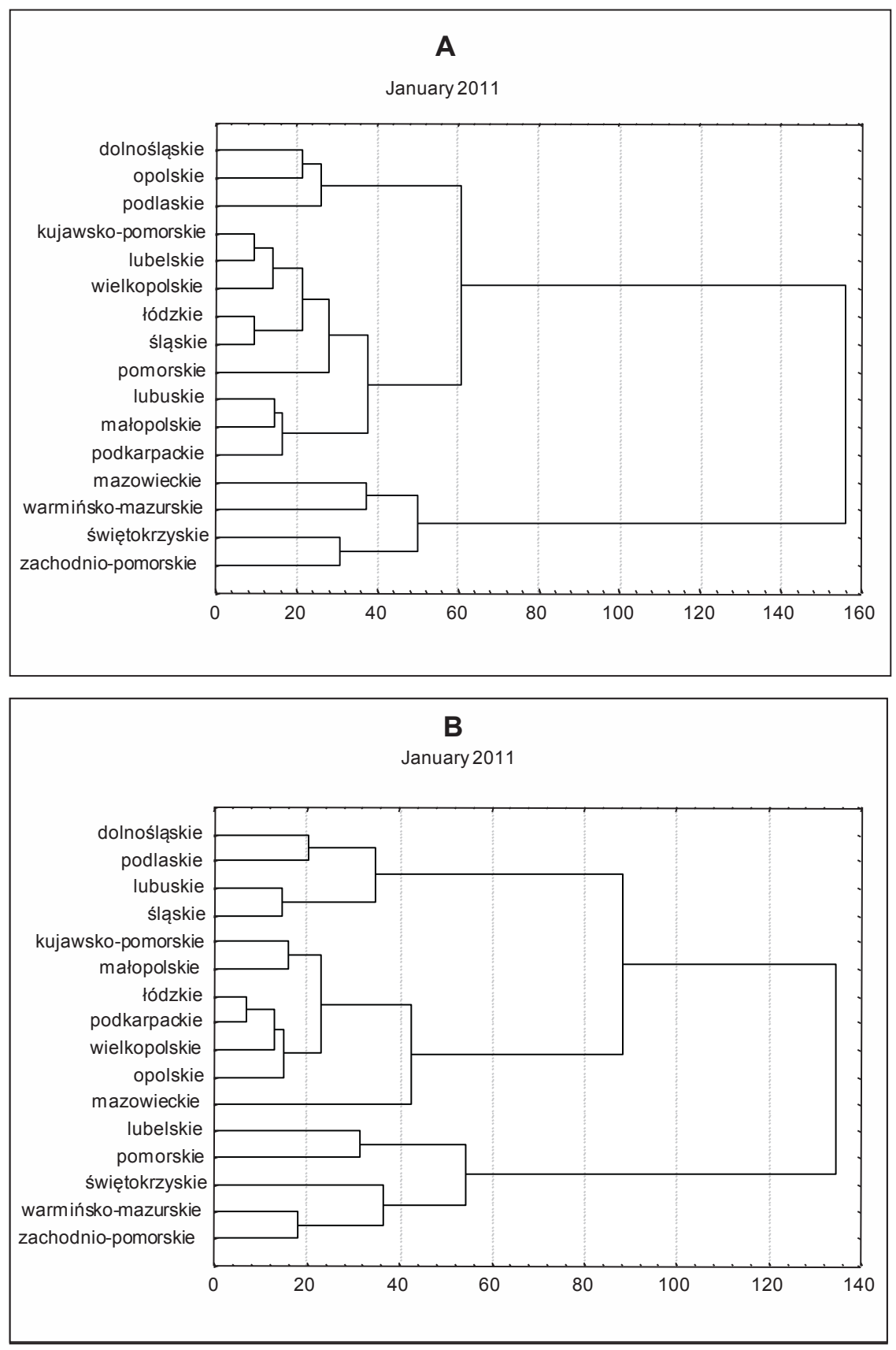

Fig. 2. Differentiation opinion (the economic balance) about the current situation (A) as well as the predicted situation of businesses (B) in the voivodeships

Source: own calculations based on GUS data 

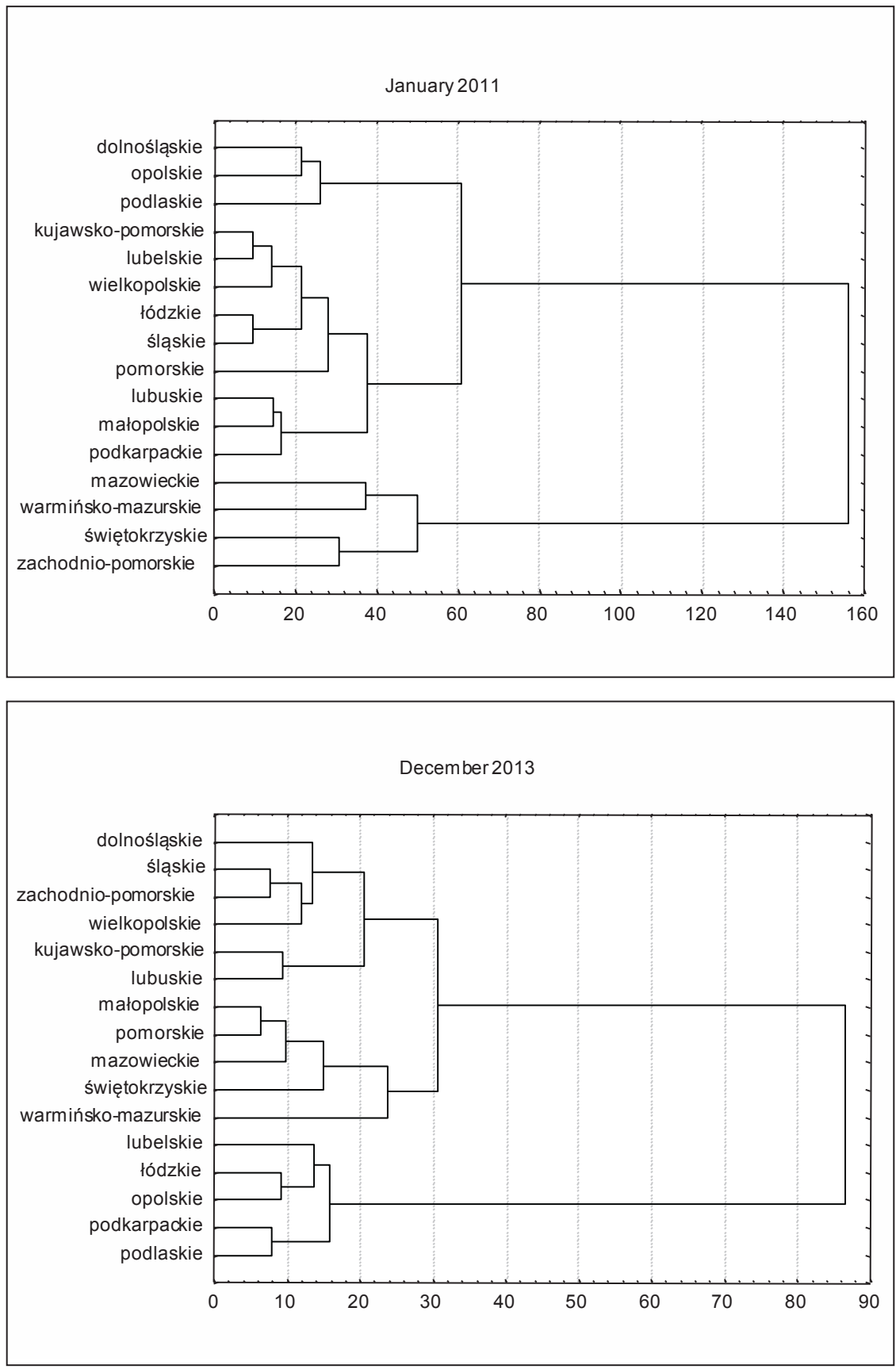

Fig. 3. Differentiation opinion (the economic balance) about the current situation of businesses in voivodeships in January 2011 and December 2013

Source: own calculations based on GUS data 


\begin{tabular}{|c|c|c|c|c|c|c|c|c|c|c|c|c|c|c|}
\hline$\vec{\partial}$ & है & $\stackrel{2}{2}$ & i) & $\begin{array}{l}\text { के } \\
\text { है }\end{array}$ & $\begin{array}{l}\overrightarrow{\tilde{N}} \\
\tilde{\sigma}\end{array}$ & $\begin{array}{l}\infty \\
\infty \\
0 \\
0\end{array}$ & \begin{tabular}{|l}
$\overrightarrow{0}$ \\
0 \\
0 \\
0
\end{tabular} & $\stackrel{0}{m}$ & $\begin{array}{l}\vec{J} \\
\overrightarrow{0}\end{array}$ & 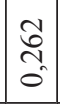 & $\begin{array}{l}\hat{\imath} \\
\hat{a} \\
0\end{array}$ & $\left|\begin{array}{l}2 \\
\vdots \\
0\end{array}\right|$ & $\begin{array}{l}\hat{\sigma} \\
\hat{0}\end{array}$ & \& \\
\hline$\frac{2}{2}$ & $\begin{array}{l}5 \\
\vdots \\
0 \\
0\end{array}$ & $\vec{\vartheta}$ & $\begin{array}{l}\text { D. } \\
\text { ma } \\
0\end{array}$ & $\begin{array}{l}\vec{n} \\
\text { an } \\
0\end{array}$ & $\begin{array}{l}0 \\
\cdots \\
0 \\
0\end{array}$ & $\begin{array}{l}\hat{n} \\
y \\
0 \\
0\end{array}$ & 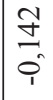 & $\begin{array}{l}\text { U্ত } \\
0 \\
0\end{array}$ & $\frac{m}{\hat{\sigma}}$ & $\begin{array}{l}0 \\
\delta \\
0 \\
0\end{array}$ & $\mid \begin{array}{c}0 \\
\Phi \\
0 \\
0\end{array}$ & 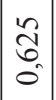 & $\begin{array}{c}8 \\
0 \\
- \\
-1\end{array}$ & $\frac{5}{0}$ \\
\hline$\frac{7}{2}$ & $\begin{array}{c}\overrightarrow{\mathrm{c}} \\
\mathrm{c} \\
\mathrm{\sigma}\end{array}$ & 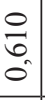 & $\begin{array}{l}\frac{m}{0} \\
0 \\
0\end{array}$ & 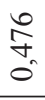 & 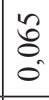 & $\begin{array}{l}\infty \\
0 \\
0 \\
0\end{array}$ & $\begin{array}{l}\tilde{b} \\
0 \\
0 \\
0\end{array}$ & $\mid \begin{array}{l}\infty \\
\infty \\
\infty \\
0 \\
0\end{array}$ & 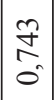 & $\begin{array}{l}\infty \\
0 \\
0 \\
0\end{array}$ & $\mid \begin{array}{c}m \\
\tilde{\infty} \\
0 \\
0\end{array}$ & $\begin{array}{c}8 \\
8 \\
-\end{array}$ & 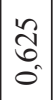 & $\div$ \\
\hline $\bar{a}$ & & & $\begin{array}{l}n \\
n \\
n \\
o\end{array}$ & $\begin{array}{l}\tilde{n} \\
\text { ô }\end{array}$ & $\frac{\infty}{=}$ & 嵩 & $\begin{array}{l}0 \\
0 \\
0 \\
0\end{array}$ & $\begin{array}{l}\curvearrowright \\
\infty \\
0 \\
0\end{array}$ & $\mid \begin{array}{c}\infty \\
\infty \\
\infty \\
0\end{array}$ & $\begin{array}{l}\vec{\sigma} \\
\hat{0}\end{array}$ & $\begin{array}{c}8 \\
\vdots \\
- \\
-1\end{array}$ & $\begin{array}{c}\infty \\
\tilde{\infty} \\
0\end{array}$ & $\left|\begin{array}{c}0 \\
0 \\
0 \\
0\end{array}\right|$ & ָิ \\
\hline$\stackrel{0}{2}$ & $\begin{array}{c}0 \\
8 \\
0 \\
0\end{array}$ & 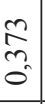 & 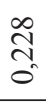 & $\begin{array}{l}\overline{\tilde{o}} \\
0 \\
i\end{array}$ & 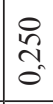 & ह̂. & 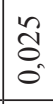 & 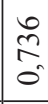 & $\begin{array}{c} \pm \\
\infty \\
0 \\
0\end{array}$ & 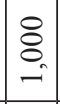 & $\begin{array}{l}\vec{\sigma} \\
\hat{\sigma}\end{array}$ & $\mid \begin{array}{l}\infty \\
\tilde{\delta} \\
0 \\
0\end{array}$ & $\mid \begin{array}{l}0 \\
0 \\
0 \\
0\end{array}$ & S్ర \\
\hline 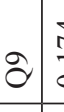 & 吉 & $\stackrel{\hat{\vartheta}_{0}}{ }$ & $\begin{array}{l}\text { N } \\
\text { o. } \\
0\end{array}$ & $\begin{array}{l}\vec{\infty} \\
\overrightarrow{0}\end{array}$ & $\begin{array}{l}n \\
2 \\
0 \\
0\end{array}$ & \begin{tabular}{|l}
$\hat{o}$ \\
$\dot{+}$ \\
0 \\
0
\end{tabular} & $\begin{array}{l}2 \\
\hat{0} \\
\end{array}$ & $\begin{array}{l}\overline{\bar{\infty}} \\
0 \\
0\end{array}$ & $\begin{array}{c}8 \\
\vdots \\
-\end{array}$ & $\begin{array}{c} \pm \\
\infty \\
0 \\
0\end{array}$ & $\begin{array}{l}\infty \\
\infty \\
0 \\
0\end{array}$ & $\underset{\sim}{\stackrel{g}{\sim}}$ & $\begin{array}{l}\hat{2} \\
\hat{0}\end{array}$ & $\exists$ \\
\hline$\approx$ & $\begin{array}{l}\infty \\
0 \\
c \\
c \\
0 \\
0\end{array}$ & 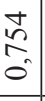 & 胥 & $\begin{array}{l}\tilde{N} \\
\text { مू } \\
0\end{array}$ & $\underset{0}{ \pm}$ & $\mid \begin{array}{l}2 \\
\hat{\tilde{n}} \\
0\end{array}$ & 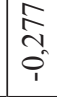 & $\stackrel{8}{-}$ & $\begin{array}{c}\vec{z} \\
\infty \\
0\end{array}$ & $\mid \begin{array}{l}0 \\
\approx \\
0 \\
0\end{array}$ & $\begin{array}{c}N \\
\infty \\
\infty \\
0\end{array}$ & $\left|\begin{array}{l}\infty \\
\infty \\
\infty \\
0\end{array}\right|$ & $\mid \begin{array}{c}\mathbb{J} \\
0 \\
0\end{array}$ & $\bar{m}$ \\
\hline$\tilde{a}$ & & 이 & $\begin{array}{l}\text { ते } \\
\text { के }\end{array}$ & $\begin{array}{l}\bar{q} \\
\text { a } \\
i\end{array}$ & $\begin{array}{l}\infty \\
\text { ? } \\
\text { ?. } \\
\text { in }\end{array}$ & $\begin{array}{l}\hat{o} \\
\dot{q} \\
\hat{i}\end{array}$ & $\underset{-1}{8}$ & $\begin{array}{l}\hat{\widehat{N}} \\
\hat{i}\end{array}$ & 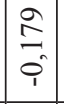 & $\begin{array}{l}2 \\
\tilde{a} \\
0 \\
0\end{array}$ & $\mid \begin{array}{l}0 \\
1 \\
0 \\
0 \\
1\end{array}$ & $\left|\begin{array}{c}0 \\
\underline{6} \\
0 \\
1\end{array}\right|$ & $\frac{y}{d}$ & $\begin{array}{l}\vec{\alpha} \\
0 \\
0 \\
0\end{array}$ \\
\hline 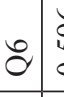 & 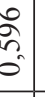 & है & $\begin{array}{l}\frac{2}{y} \\
\text { on }\end{array}$ & $\begin{array}{l}\infty \\
0 \\
0 \\
0 \\
0\end{array}$ & $\begin{array}{l}2 \\
\hat{\sigma} \\
0\end{array}$ & $\underset{0}{8}$ & \begin{tabular}{|l}
$\hat{q}$ \\
$\hat{q}$ \\
0 \\
0
\end{tabular} & 命 & $\mid \begin{array}{l}\hat{o} \\
\dot{q} \\
0\end{array}$ & $\begin{array}{l}1 \\
0 \\
0 \\
0\end{array}$ & $\mid \begin{array}{c}\bar{a} \\
\dot{g} \\
0\end{array}$ & $\left|\begin{array}{l}0 \\
0 \\
0 \\
0 \\
0\end{array}\right|$ & $\left|\begin{array}{l}n \\
n \\
0 \\
0\end{array}\right|$ & $\begin{array}{l}\infty \\
\infty \\
0 \\
0\end{array}$ \\
\hline$\approx$ & $\begin{array}{c}0 \\
0 \\
0 \\
0 \\
1\end{array}$ & $\begin{array}{l}1 \\
0 \\
0 \\
0 \\
0\end{array}$ & $\begin{array}{l}\infty \\
\stackrel{\infty}{0} \\
0\end{array}$ & ' & $\stackrel{8}{8}$ & $\begin{array}{l}2 \\
\hat{\sigma} \\
0\end{array}$ & $\mid \begin{array}{l}\infty \\
\text { a } \\
\text { n. } \\
0 \\
1\end{array}$ & $\underset{0}{\Xi}$ & $\mid \begin{array}{l}n \\
\tilde{z} \\
0 \\
0\end{array}$ & $\begin{array}{l}0 \\
n \\
n \\
0\end{array}$ & $\mid \begin{array}{l}\infty \\
\underline{1} \\
0\end{array}$ & $\left|\begin{array}{l}n \\
\delta \\
0 \\
0\end{array}\right|$ & $\left|\begin{array}{c}0 \\
0 \\
0 \\
0\end{array}\right|$ & $\bar{\beth}$ \\
\hline$d$ & 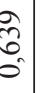 & $\begin{array}{l}0 \\
\delta \\
0 \\
0 \\
0\end{array}$ & $\begin{array}{l}\text { ర్ } \\
\text { है } \\
\text { ?. }\end{array}$ & $\underset{-}{8}$ & $\begin{array}{l}0 \\
8 \\
0 \\
0\end{array}$ & $\mid \begin{array}{l}\infty \\
0 \\
0 \\
0\end{array}$ & $\mid \begin{array}{l}\vec{o} \\
+ \\
0 \\
0\end{array}$ & $\mid \begin{array}{l}\tilde{z} \\
\tilde{n} \\
0\end{array}$ & $\frac{\vec{\infty}}{\overrightarrow{0}}$ & $\begin{array}{l}\vec{n} \\
0 \\
0 \\
1\end{array}$ & $\begin{array}{l}\tilde{n} \\
\tilde{0} \\
0\end{array}$ & $\mid$\begin{tabular}{l}
0 \\
\multirow{2}{+}{} \\
0
\end{tabular} & $\left|\begin{array}{l}\vec{n} \\
\tilde{0} \\
0\end{array}\right|$ & $\begin{array}{l}\text { ¿े } \\
\text { oे }\end{array}$ \\
\hline$\approx$ & \begin{tabular}{c}
$\hat{n}$ \\
\multirow{2}{n}{} \\
0
\end{tabular} & $\begin{array}{l}n \\
0 \\
n \\
0 \\
0\end{array}$ & $\stackrel{8}{-}$ & $\begin{array}{l}\text { S. } \\
\text { مू. } \\
0\end{array}$ & $\begin{array}{l}\infty \\
\stackrel{\infty}{0} \\
0\end{array}$ & $\frac{1}{\stackrel{y}{f}}$ & \begin{tabular}{|l}
$\hat{\vec{N}}$ \\
$\hat{i}$
\end{tabular} & $\begin{array}{l}\tilde{N} \\
\tilde{n} \\
0\end{array}$ & $\mid \begin{array}{c}\mathbb{N} \\
\hat{n} \\
0\end{array}$ & 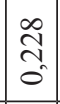 & $\begin{array}{l}n \\
n \\
0 \\
0\end{array}$ & $\begin{array}{l}0 \\
0 \\
0 \\
0\end{array}$ & $\mid \begin{array}{l}0 \\
0 \\
0 \\
0\end{array}$ & i \\
\hline$\approx$ & $\begin{array}{l}\Delta \\
0 \\
0^{\circ}\end{array}$ & $\begin{array}{l}8 \\
\vdots \\
-\end{array}$ & 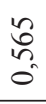 & $\begin{array}{l}\tilde{O} \\
\infty \\
0 \\
0\end{array}$ & $\begin{array}{l}\widetilde{1} \\
0 \\
0 \\
0\end{array}$ & $\begin{array}{l}n \\
0 \\
0 \\
0\end{array}$ & $\begin{array}{l}0 \\
\dot{f} \\
\hat{i} \\
i\end{array}$ & $\begin{array}{l}\text { 苋 } \\
\text { o } \\
0\end{array}$ & $\mid \begin{array}{c}2 \\
\hat{f} \\
0 \\
0\end{array}$ & $\begin{array}{c}2 \\
2 \\
\vdots \\
0\end{array}$ & $\begin{array}{l}0 \\
0 \\
n \\
0\end{array}$ & $\begin{array}{l}0 \\
0 \\
0 \\
0\end{array}$ & $\mid \begin{array}{l}\overrightarrow{\tilde{p}} \\
\dot{0}\end{array}$ & $\frac{2}{0}$ \\
\hline$\vec{a}$ & $\varepsilon_{1}$ & $\begin{array}{l}\frac{⿱}{+} \\
0 \\
0\end{array}$ & $\begin{array}{l}\text { ñ } \\
\text { on }\end{array}$ & ठुे & $\begin{array}{l}0 \\
0 \\
0 \\
i\end{array}$ & $\begin{array}{l}0 \\
\text { n. } \\
0\end{array}$ & 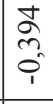 & $\begin{array}{l}\infty \\
\infty \\
\tilde{0} \\
0\end{array}$ & $\begin{array}{c} \pm \\
\stackrel{0}{0} \\
\end{array}$ & $\begin{array}{l}\tilde{8} \\
0 \\
0\end{array}$ & $\begin{array}{l}2 \\
0 \\
0\end{array}$ & $\begin{array}{l}\overrightarrow{\widehat{\hat{N}}} \\
\hat{0}\end{array}$ & $\mid \begin{array}{l}\overrightarrow{0} \\
0 \\
0\end{array}$ & $\begin{array}{l}\hat{\hat{O}} \\
0 \\
0\end{array}$ \\
\hline & & & & & 0 & & 0 & & 10 & & $\bar{a}$ & $\bar{a}$ & $\overrightarrow{0}$ & \\
\hline
\end{tabular}

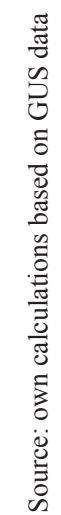




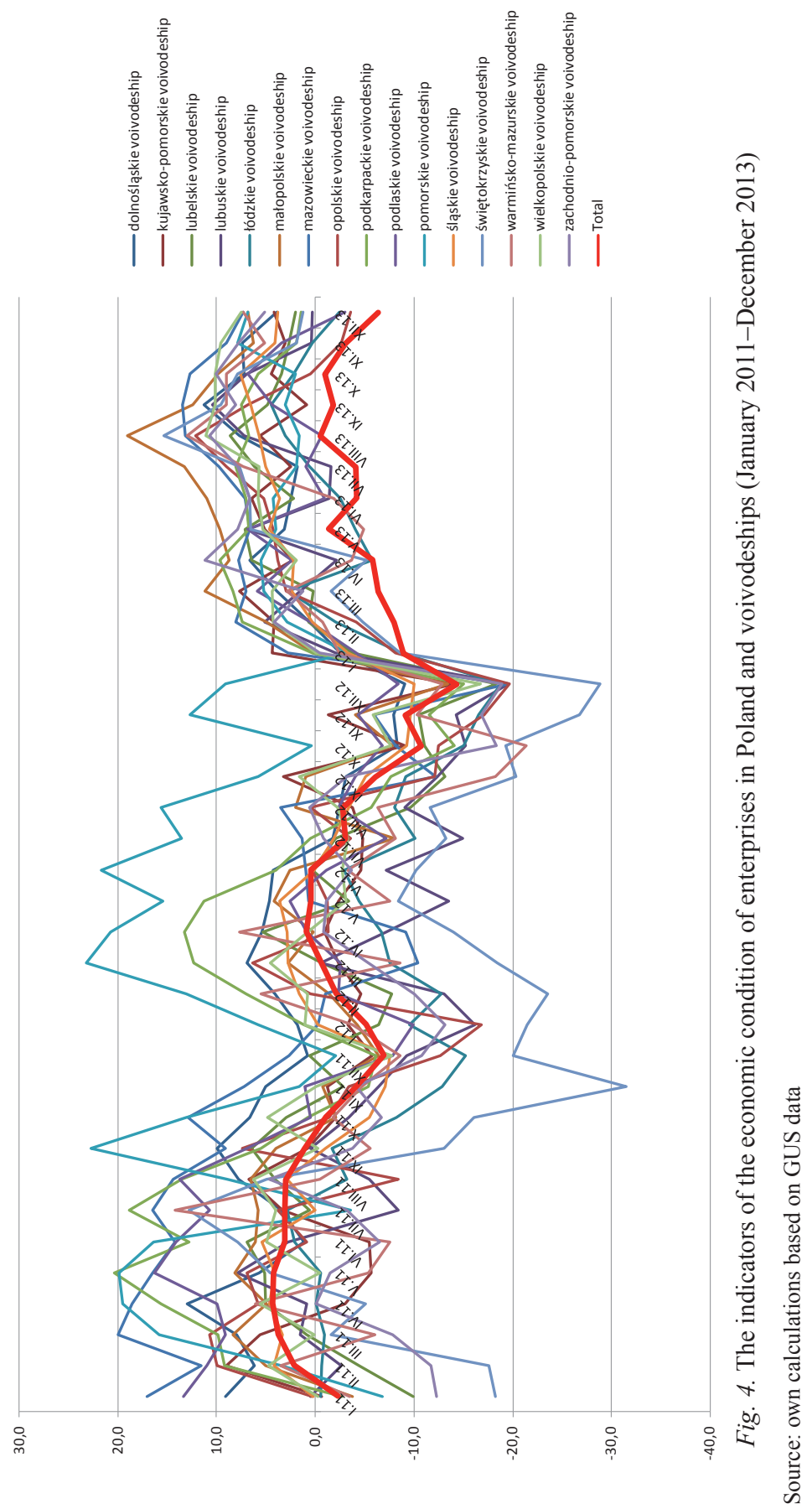


There was an even stronger relationship between these elements and the expected economic situation, e.g. Q9 and Q11 ( $\mathrm{r}=0.898)$. As is apparent from Table 1, the forecast of the performance of business (Q8-Q14) was primarily conditioned by the production envisaged by the entrepreneurs (Q11). In turn, the assessment of the current situation (Q1) was determined by the backlog (Q2). In voivodeships the balance of the answer to this question (Q2) strongly correlated with the assessment of current production (Q4; $r=0.803)$, as well as the overall assessment of the current situation $(\mathrm{Q} 1 ; \mathrm{r}=0.744)$ and the expected economic situation of enterprises (Q8; $r=0.754)$.

The spatial aspect of the economic condition in the processing industry can also be analysed through the prism of the composite indicators. On the basis of variables for which respondents are asked both in the diagnostic and prognostic part of the survey, the CSO develops and publishes an indicator of overall economic climate. It allows for a more general, synthetic look at the regional fluctuations (cycles) of the economic condition in the processing industry. Spatial variations of this indicator in the selected time periods are shown in Figure 4, and the similarity of monthly assessments of the economic climate in the manufacturing sector from January 2011 to December 2013 in voivodeships is shown in Figure 5. The largest similarity of this sentiment with respect to the overall economic climate in Polish manufacturing was shown in Podkarpackie $(r=0.788)$ and Podlaskie $(r=0.742)$ Voivodeships, while the smallest in Kujawsko-Pomorskie Voivodeship $(r=0.237)^{10}$.

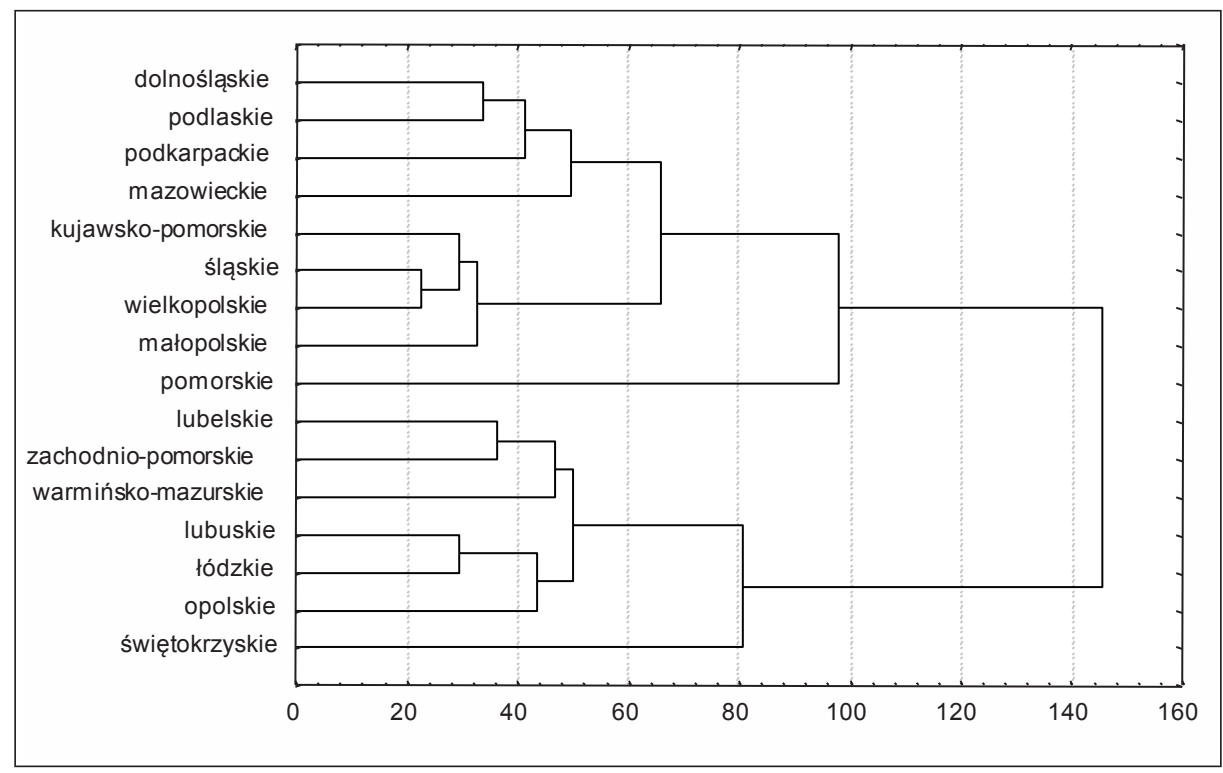

Fig. 5. The similarity of monthly assessments of the economic climate in the manufacturing sector from January 2011 to December 2013 in voivodeships

Source: own calculations based on GUS data

10 e.g. Carlino, Sill, 2001. 
It seems that studies on the spatial differentiation of economic sentiment in the manufacturing sector may complement the essential object of the industrial geography study with a new quality context. Moreover, in the era of the knowledge economy and the information society, the issues related to the diagnosis of current processes taking place in the socio-economic sphere become crucial from the point of view of the individual or society. Data on the economic situation are among the most recent data published by the Central Statistical Office describing manufacturing. Information about the economic sentiments is available in the month in which the study is conducted. Their cyclical nature, regularity and universality may be useful in creating fully valuable information, increasing knowledge about the surrounding world and the major trends of change in the modern industry, which not only enriches the knowledge of the individual, but also supports the management processes in the region. We need to be aware that economic condition surveys do not provide precise information on the volume of production, sales, investments and employment. However, as shown by the experience of the OECD countries, they can be a tool for tracking the effects of the regional policy and drawing conclusions as to its desired future directions. The results of this study allow capturing almost "real-time" sensitivity of the sector to changes in economic conditions, including seasonal variations, and analysing these phenomena in the Polish territorial systems.

\section{References}

Badanie koniunktury gospodarczej. (2011). Warszawa: GUS, Departament Przedsiębiorstw, 8-11.

Bal-Woźniak, T. (2009). Infrastruktura systemu innowacyjnego jako czynnik transformacji struktur przemysłowych. Prace Komisji Geografii Przemystu Polskiego Towarzystwa Geograficznego, $12,45-58$.

Bazydło, A., Smętkowski, M., Wieloński, A. (2002). Inwestycje w specjalnych strefach ekonomicznych a przekształcenia strukturalne w przemyśle Polski. Prace Komisji Geografii Przemystu Polskiego Towarzystwa Geograficznego, 3, 135-148.

Borowiec, M., Dorocki, S., Jenner, B. (2009). Wpływ zasobów kapitału ludzkiego na kształtowanie społeczeństwa informacyjnego i innowacyjności struktur przemysłowych. Prace Komisji Geografii Przemystu Polskiego Towarzystwa Geograficznego, 13, 95-109.

Brezdeń, P., Spallek, W. (2013). Efektywność firm korporacyjnych o dobrym standingu w województwie dolnośląskim w ujęciu przestrzennym. Prace Komisji Geografii Przemystu Polskiego Towarzystwa Geograficznego, 14, 81-94.

Brocka-Palacz, B. (1990). Rola państwa w kształtowaniu zmian struktury przemysłu w gospodarce rynkowej. Gospodarka Narodowa, 1, 7-8.

Brzozowski, T. (2013). Wiedza jako podstawowy czynnik rozwoju przemysłu i usług. Prace Komisji Geografii Przemystu Polskiego Towarzystwa Geograficznego, 21, 390-404.

Carlino, G., Sill, K. (2001). Regional income fluctuations. Common trends and common cycles. Review of Economics and Statistics, 83(3), 446-456.

Czapliński, P. (2000). Przemysł drzewny na Pomorzu Środkowym w procesie przeobrażeń gospodarczych. Prace Komisji Geografii Przemystu Polskiego Towarzystwa Geograficznego, 1, 67-76.

Czapliński, P. (2003). Polityka regionalna a rozwój przemysłu w rejonie słupskim. Prace Komisji Geografii Przemystu Polskiego Towarzystwa Geograficznego, 4, 67-78.

Czapliński, P. (2008). Problematyka badawcza przemysłu w geografii na tle nauk ekonomicznych. Prace Komisji Geografii Przemystu Polskiego Towarzystwa Geograficznego, 11, 46-52. 
Czapliński, P. (2008). Zmiany struktury przestrzennej przemysłu w subregionie słupskim. Prace Komisji Geografii Przemystu Polskiego Towarzystwa Geograficznego, 10, 23-34.

Czapliński, P. (2011). Funkcjonowanie przemysłu przetwórstwa rybnego w Polsce w okresie kryzysu gospodarczego. Prace Komisji Geografii Przemystu Polskiego Towarzystwa Geograficznego, 17, $114-128$.

Czapliński, P. (2013). Formowanie się nowej struktury przestrzennej przemysłu przetwórstwa rybnego w Polsce. Prace Komisji Geografii Przemystu Polskiego Towarzystwa Geograficznego, 21, 121-132.

Czapliński, P., Stawarska, A. (2010). Przejawy procesu globalizacji w sferze produkcji na przykładzie Scania Production Słupsk S.A. Prace Komisji Geografii Przemystu Polskiego Towarzystwa Geograficznego, 16, 176-186.

Czepczyński, M. (2001). Struktura inwestycji zagranicznych w Gdyni. Prace Komisji Geografii Przemystu Polskiego Towarzystwa Geograficznego, 2, 75-85.

Czepczyński, M. (2002). Transformacje struktur przemysłowych na terenie województwa pomorskiego. Prace Komisji Geografii Przemystu Polskiego Towarzystwa Geograficznego, 3, 87-91.

Domański, B., Guzik, R., Gwosdz, K., Dej, M. (2013). The crisis and beyond: the dynamics and restructuring of automotive industry in Poland. International Journal of Automotive Technology and Management, 13(2), 151-165.

Domański, B. (2000). Regionalne zróżnicowanie inwestycji zagranicznych w przemyśle Polski. Kraków: Uniwersytet Jagielloński, Instytut Geografii i Gospodarki Przestrzennej.

Domański, B. (2001a). Kapitat zagraniczny w przemyśle Polski. Kraków: Uniwersytet Jagielloński, Instytut Geografii i Gospodarki Przestrzennej.

Domański, B. (2001b). Poland: labour and the relocation of manufacturing from the EU. In: G. Gradev (ed.), CEE countries in EU companies' strategies of industrial restructuring and relocation. Brussels: European Trade Union Institute, 21-49.

Domański, B. (2003a). Economic trajectory, path dependency and strategic intervention in an old industrial region: the case of Upper Silesia. In: R. Domański (ed.), Recent advances in urban and regional studies. Warsaw: Polish Academy of Sciences, Committee for Space Economy and Regional Planning, 133-153.

Domański, B. (2003b). Korporacje ponadnarodowe a transfer wiedzy w przemyśle Polski. In: A. Kukliński (ed.), Gospodarka oparta na wiedzy. Perspektywy Banku Światowego. Warszawa: KBN, Biuro Banku Światowego w Polsce, 161-164.

Domański, B. (2003c). Transnational corporations in Polish manufacturing: their embeddedness and impact on Poland's role in the European economy. In: A. Kukliński, B. Skuza (eds.), Europe in the perspective of global change. Warsaw: The Polish Association for the Club of Rome/Oficyna Wydawnicza Rewasz, 315-322.

Domański, B. (2003d). Zagraniczne inwestycje przemysłowe a obszary metropolitalne w Polsce. Prace Komisji Geografii Przemystu Polskiego Towarzystwa Geograficznego, 4, 9-18.

Domański, B. (2004). Local and regional embeddedness of foreign industrial investors in Poland. Prace Geograficzne, 114, 37-54. Kraków: Uniwersytet Jagielloński.

Domański, B. (2005). Transnational corporations and the post-socialist economy: learning the ropes and forging new relationships in contemporary Poland. In: C. Alvstam, E. Schamp (eds.), Linking Industries across the World: Processes of Global Networking. Ashgate: Aldershot, 147-172.

Domański, B. (2006). Polski przemysł na tle przemysłu Europy Środkowej i Wschodniej. Prace Komisji Geografii Przemystu Polskiego Towarzystwa Geograficznego, 8, 27-36.

Domański, B. (2000). Some aspects of the development of Polish manufacturing in the perspective of knowledge-based economy. In: A. Kukliński (ed.), The knowledge-based economy. The European challenges of the $21^{\text {st }}$ century. Warsaw: State Committee for Scientific Research, 281-287.

Domański, B., Dej, M., Działek, J., Gwosdz, K., Sobala-Gwosdz, A. (2011). Znaczenie przemystu dla , inteligentnego i trwatego" rozwoju Polski Wschodniej oraz podejmowanych działań dotycza- 
cych jego restrukturyzacji i modernizacji. Ekspertyza przygotowana na zlecenie Departamentu Programów Ponadregionalnych Ministerstwa Rozwoju Regionalnego. Kraków.

Domański, B., Guzik R., Gwosdz, K. (2005). The new spatial organization of automotive industry in Poland in the context of its changing role in Europe. Studia Regionalia, 15, 153-171.

Domański, B., Gwosdz, K. (2005a). Rola specjalnej strefy ekonomicznej. Spojrzenie syntetyczne. In: B. Domański, K. Gwosdz (eds.), Dziesięć lat doświadczeń pierwszej polskiej specjalnej strefy ekonomicznej. Mielec 1995-2005. Kraków-Mielec: Uniwersytet Jagielloński, Instytut Geografii i Gospodarki Przestrzennej, 195-202.

Domański, B., Gwosdz, K. (2005b). Czynniki zakorzenienia inwestorów w strefie mieleckiej. In: B. Domański, K. Gwosdz (eds.), Dziesięć lat doświadczeń pierwszej polskiej specjalnej strefy ekonomicznej. Mielec 1995-2005, Kraków-Mielec: Uniwersytet Jagielloński, Instytut Geografii i Gospodarki Przestrzennej, 167-180.

Domański, B., Gwosdz, K., Huculak, M., Wiedermann, K. (2005). Oddziaływanie SSE Euro-Park Mielec na otoczenie lokalne. Powiązania firm i efekty mnożnikowe. In: B. Domański, K. Gwosdz (eds.), Dziesięć lat doświadczeń pierwszej polskiej specjalnej strefy ekonomicznej. Mielec 19952005. Kraków-Mielec: Uniwersytet Jagielloński, Instytut Geografii i Gospodarki Przestrzennej, 89-132.

Domański, B., Stryjakiewicz, T. (2003). Post-communist industrial transformation and its regional dimension. In: G. Stöber (ed.), Der Transformationsprozess in (Ost-) Deutschland und in Polen. Hannover: Verlag Hahnsche Buchhandlung, 46-71.

Dorocki, S., Borowiec, M., Boguś, M. (2013). Przestrzenne zróżnicowanie rozwoju przemysłu biotechnologicznego. Prace Komisji Geografii Przemystu Polskiego Towarzystwa Geograficznego, $21,94-120$.

Fedan, R. (2006). Przemiany w przemyśle mleczarskim w regionie przemyskim. Prace Komisji Geografii Przemystu Polskiego Towarzystwa Geograficznego, 8, 212-218.

Gierańczyk, W. (2003). Wybrane aspekty konkurencyjności polskiego przemysłu w dobie globalnych wyzwań rozwoju. Prace Komisji Geografii Przemyslu Polskiego Towarzystwa Geograficznego, $6,77-86$.

Gierańczyk, W. (2008a). Badanie struktur przemysłowych w Polsce w dobie globalizacji ze szczególnym uwzględnieniem struktury przestrzennej. Prace Komisji Geografii Przemystu Polskiego Towarzystwa Geograficznego, 11, 26-39.

Gierańczyk, W. (2008b). Problematyka definiowania zmian w tendencjach lokalizacyjnych przedsiębiorstw przemysłowych w dobie globalizacji. Prace Komisji Geografii Przemystu Polskiego Towarzystwa Geograficznego, 11, 86-97.

Gierańczyk, W. (2009). Przemysł zaawansowanej technologii a konkurencyjność przemysłowa krajów UE. In: Z. Zioło, M. Borowiec (eds.), Problematyka XXV Międzynarodowej Konferencji Naukowej nt. Procesy transformacji przemystu i ustug $w$ regionalnych $i$ krajowych uktadach przestrzennych. Warszawa-Kraków: Komisja Geografii Przemysłu PTG, Zakład Przedsiębiorczości i Gospodarki Przestrzennej IG UP, 36-37.

Gierańczyk, W. (2010a). Innowacyjność przedsiębiorstw woj. kujawsko-pomorskiego i w Polsce. In: M. Bieliński, A. Potoczek (eds.), Polityka innowacyjna w województwie kujawsko-pomorskim. Toruń: Urząd Marszałkowski Województwa Kujawsko-Pomorskiego, 285-317.

Gierańczyk, W. (2010b). Innovativeness of the European Union against the leading world economies. Problems of Geography, Bulgarian Academy of Sciences, 3-4, 40-47.

Gierańczyk, W. (2010c). Development of high technologies as an indicator of modern industry in the EU. Bulletin of Geography. Socio-economic Series, 14, 23-36.

Gierańczyk, W. (2012). Kapitał ludzki w przemyśle jako źródło przewagi konkurencyjnej w państwach UE. Prace Komisji Geografii Przemystu Polskiego Towarzystwa Geograficznego, 19, 28-44. 
Gierańczyk, W., Kordowska, A. (2013). Innowacyjność przedsiębiorstw przemysłowych i usługowych w województwie kujawsko-pomorskim w latach 2008-2010. Wiadomości Statystyczne, 5, 83-97. Warszawa: GUS, Polskie Towarzystwo Statystyczne.

Gierańczyk, W., Kordowska, A. (2014). Przeszkody dla innowacji w ocenie przedsiębiorstw przemysłowych z województwa kujawsko-pomorskiego. Wiadomości Statystyczne, 2, 64-80.

Gierańczyk, W., Rachwał, T. (2010). Innovativeness of industry as a symptom of restructuring processes in Poland against the background of the Eastern European Union countries. In: Regional Responses and Global Shifts: Actors, Institutions and Organisations. Abstracts of Regional Studies Association Annual International Conference 2010, Pec: RSA, 67.

Gierańczyk, W., Rachwał, T. (2012). Structural changes in the industry of Poland against the background of eastern European Union states. Quaestiones Geographicae, 31(2), 83-93.

Gierańczyk, W., Stańczyk, A. (2002). Okręgi przemysłowe w Polsce u progu XXI wieku. Prace Komisji Geografii Przemystu Polskiego Towarzystwa Geograficznego, 3, 61-69.

Gierańczyk, W., Stańczyk, A. (2003). Korporacje międzynarodowe w przestrzeni globalnej. Prace Komisji Geografii Przemystu Polskiego Towarzystwa Geograficznego, 5, 73-84.

Gurbała, M. (2010). Przemysł high-tech a poziom rozwoju społeczno-gospodarczego krajów. Prace Komisji Geografii Przemystu Polskiego Towarzystwa Geograficznego, 16, 187-200.

Gwosdz, K., Domański, B. (2008). Social consequences of delocalization in labour-intensive industries: the experience of old and new members of the EU. In: L. Labrianidis (ed.), The Moving Frontier: The Changing Geography of Production in Labour-Intensive Industries. Ashgate: Aldershot, 101-122.

Hryniewicz, J. (2013). Przemysł, gospodarka oparta na wiedzy i wspólna europejska polityka przemysłowa. Prace Komisji Geografii Przemysłu Polskiego Towarzystwa Geograficznego, 21, 31-46.

Huculak, M. (2006). Procesy współkształtujące globalizację przemysłu piwowarskiego Europy. Prace Komisji Geografii Przemystu Polskiego Towarzystwa Geograficznego, 8, 152-159.

Huculak, M. (2008). Inwestycje zagraniczne w przemyśle Krakowa. Prace Komisji Geografii Przemystu Polskiego Towarzystwa Geograficznego, 10, 230-244.

Jaworski, J. (2006). Offset jako czynnik rozwoju przemysłu. Prace Komisji Geografii Przemystu Polskiego Towarzystwa Geograficznego, 8, 179-191.

Kilar, W., Cieluch, M. (2008). Kształtowanie się i organizacja przestrzenna korporacji ponadnarodowej Honda. Prace Komisji Geografii Przemystu Polskiego Towarzystwa Geograficznego, 10, $188-203$.

Kitowski, J.(2010). Wpływ kryzysu gospodarczego na funkcjonowanie specjalnych stref ekonomicznych w Polsce. In: M. Barwiński (ed.), Obszary metropolitalne we wspótczesnym środowisku geograficznym. Łódź: Wydział Nauk Geograficznych UŁ, 61-73.

Kitowski, J. (2011). Wpływ kryzysu finansowego i gospodarczego na efekty funkcjonowania specjalnych stref ekonomicznych w Polsce. In: B. Namyślak (ed.), Przekształcenia regionalnych struktur funkcjonalno-przestrzennych. Wspótczesne kierunki przemian społeczno-ekonomicznych. Rozprawy Naukowe Instytutu Geografii i Rozwoju Regionalnego, 19, 23-39.

Kitowski, J. (2012). Próba oceny efektywności finansowej działalności specjalnych stref ekonomicznych w Polsce. In: R. Borowiecki, M. Dziura (eds.), Globalne i regionalne wyzwania restrukturyzacji przedsiębiorstw i gospodarek. Kraków: Uniwersytet Ekonomiczny w Krakowie. Katedra Ekonomiki i Organizacji Przedsiębiorstw, Fundacja Uniwersytetu Ekonomicznego w Krakowie, 369-388.

Kłysik, B. (1998). Charakterystyka struktury i przekształceń przemysłu m. Łodzi. In: Studium uwarunkowań i kierunków zagospodarowania przestrzennego m. Łodzi. Łódź: „Gorgul i Wiśniewski, Urbanistyka - Architektura" Sp. z o.o.

Komornicki, T. (2006). Eksport w ujęciu regionalnym jako miernik rozwoju przemysłu. Prace Komisji Geografii Przemystu Polskiego Towarzystwa Geograficznego, 8, 167-178. 
Kurek, S. (2009). Starzenie się ludności na obszarach przemysłowych w Polsce. Prace Komisji Geografii Przemystu Polskiego Towarzystwa Geograficznego, 14, 104-120.

Kwiatek-Sołtys, A. (2000). Miejsce przemysłu w strukturze funkcjonalnej małych miast regionu krakowskiego. Prace Komisji Geografii Przemystu Polskiego Towarzystwa Geograficznego, 1, 89-95.

Lizak, P. (2009). Wpływ koncernu Fiat na kształtowanie się przemysłu samochodów osobowych w Polsce. Prace Komisji Geografii Przemystu Polskiego Towarzystwa Geograficznego, 12, 79 86.

Luchter, L. (2002). Proces deregulacji elektroenergetyki w Polsce na tle przemian strukturalnych tego sektora w krajach Unii Europejskiej. Prace Komisji Geografii Przemystu Polskiego Towarzystwa Geograficznego, 3, 99-113.

Makieła, Z. (2002). Przekształcenia Skawińskich Zakładów Koncentratów Spożywczych jako przejaw procesu globalizacji. Prace Komisji Geografii Przemystu Polskiego Towarzystwa Geograficznego, $3,149-154$.

Makieła, Z. (2003). Wyniki realizacji programów restrukturyzacji górnictwa węgla kamiennego po 1989 r. Prace Komisji Geografii Przemystu Polskiego Towarzystwa Geograficznego, 4, 57-66.

Matykowski, R., Tobolska, A. (2009). Funkcjonowanie zakładów przemysłowych XXI wieku na przykładzie Swedwood Poland i Volkswagen Motor Polska Sp. z o.o. Analiza dojazdów do pracy. Prace Komisji Geografii Przemystu Polskiego Towarzystwa Geograficznego, 14, 65-75.

May, J. (2002). Typy przekształceń miejskich obszarów przemysłowych w łatach 90 -tych - przykład Łodzi. Prace Komisji Geografii Przemyshu Polskiego Towarzystwa Geograficznego, 3, 123-134.

Mikołajkiewicz, Z. (2001). Przedmiotowa struktura inwestycji przemysłowych wyrazem przemian strukturalnych w polskim przemyśle. Prace Komisji Geografii Przemystu Polskiego Towarzystwa Geograficznego, 2, 21-34.

Misztal, S. (2000). Regionalne efekty procesu prywatyzacji przemysłu w Polsce w latach 1989-1995. Prace Komisji Geografii Przemystu Polskiego Towarzystwa Geograficznego, 1, 23-33.

Misztal, S. (2003). Transformacja własnościowa działalności przemysłowej w Polsce według województw. Prace Komisji Geografii Przemystu Polskiego Towarzystwa Geograficznego, 5, 9-30.

Mrozińska, A. (2013). Zmiany strukturalne w przemyśle przetwórczym według województw w latach 1999-2010. Prace Komisji Geografii Przemystu Polskiego Towarzystwa Geograficznego, 21, $157-172$.

Musielak, J. (2002). Procesy restrukturyzacji w przemyśle okrętowym (na przykładzie Stoczni Szczecińskiej S.A.). Prace Komisji Geografii Przemystu Polskiego Towarzystwa Geograficznego, $3,155-166$.

Niemczak, M. (2008). Przemiany struktur polskiego przemysłu cukrowniczego jako efekt procesu restrukturyzacji. Prace Komisji Geografii Przemystu Polskiego Towarzystwa Geograficznego, 10, $109-122$.

Niemczak, M. (2009). Wpływ procesów globalizacji i integracji europejskiej na przekształcenia struktur polskiego przemysłu cukrowniczego. Prace Komisji Geografii Przemysłu Polskiego Towarzystwa Geograficznego, 12, 87-96.

Paszkowski, M. (1996). Zmiany strukturalne przemystu. Metody badania i tendencje światowe a transformacje w krajach Europy Środkowo-Wschodniej. Kraków: Uniwersytet Jagielloński.

Piasecka, K. (2001). Skala i struktura inwestycji zagranicznych w polskim przemyśle. Prace Komisji Geografii Przemystu Polskiego Towarzystwa Geograficznego, 2, 65-74.

Rachwał, T. (2002a). Funkcjonowanie Krakowskich Zakładów Elektronicznych „Telpod” w świetle przemian w polskim przemyśle elektronicznym. Prace Komisji Geografii Przemystu Polskiego Towarzystwa Geograficznego, 3, 167-180.

Rachwał, T. (2002b). Proces restrukturyzacji Zakładów Mięsnych „Nisko” S.A. jako potencjalny czynnik aktywizacji rolniczej bazy surowcowej północnej części województwa podkarpackiego. Prace Komisji Geografii Przemystu Polskiego Towarzystwa Geograficznego, 3, 181-190. 
Rachwał, T. (2003). Proces restrukturyzacji przedsiębiorstw przemysłowych w Polsce PołudniowoWschodniej (na wybranych przykładach). Prace Komisji Geografii Przemystu Polskiego Towarzystwa Geograficznego, 4, 79-88.

Rachwał, T. (2005). Zachowania głównych przedsiębiorstw przemysłowych w strukturze obszaru metropolitalnego. In: Z. Makieła, T. Marszał (eds.), Infrastruktura techniczno-ekonomiczna w obszarach metropolitarnych. Biuletyn Komitetu Przestrzennego Zagospodarowania PAN, 222, $158-169$.

Rachwał, T. (2008). Problematyka badawcza funkcjonowania przedsiębiorstw przemysłowych. Prace Komisji Geografii Przemystu Polskiego Towarzystwa Geograficznego, 11, 53-85.

Rachwał, T. (2010a). Problematyka badawcza zmian powiązań przestrzennych przedsiębiorstw przemysłowych. Studia i Prace Uniwersytetu Ekonomicznego w Krakowie, 8, 157-176.

Rachwał, T. (2010b). Struktura przestrzenna i działowa przemysłu Polski na tle Unii Europejskiej w dwudziestolecie rozpoczęcia procesów transformacji systemowej. Prace Komisji Geografii Przemystu Polskiego Towarzystwa Geograficznego, 16, 105-124.

Rachwał, T. (2011a).Industrial restructuring in Poland and other European Union states in the era of economic globalization. Procedia-Social and Behavioral Sciences, 19, 1-10.

Rachwał, T. (2011b). Transformations of the Employment Structure as an Expression of the Transformation of Polish Industry against the Background of the European Union. Bulletin of Geography. Socio-economic series, 15(1), 5-25.

Rachwał, T. (2011c). Wpływ kryzysu na zmiany produkcji przemysłowej w Polsce. Prace Komisji Geografii Przemystu Polskiego Towarzystwa Geograficznego, 17, 99-113.

Rachwał, T. (2012). Innowacyjność przedsiębiorstw przemysłowych jako czynnik rozwoju miast. Studia Komitetu Przestrzennego Zagospodarowania Kraju PAN, 141, 135-152.

Rachwał, T. (2013). Rola przedsiębiorstw przemysłowych w rozwoju gospodarki opartej na wiedzy. Prace Komisji Geografii Przemystu Polskiego Towarzystwa Geograficznego, 21, 189-211.

Rachwał, T., Wiedermann, K. (2008). Multiplier effects in regional development: The case of the motor vehicle industry in Silesian voivodeship (Poland). Quaestiones Geographicae, 27B/1, 67-80.

Rachwał, T., Wiedermann, K., Kilar, W. (2008). Wydajność i koszty pracy jako czynniki konkurencyjności przemysłu regionów Polski w Unii Europejskiej w ujęciu regionalnym. In: D. Innicki, K. Janc (eds.), Przeksztatcenia regionalnych struktur funkcjonalno-przestrzennych „Europa bez granic - nowe wyzwania”. Wrocław: Instytut Geografii i Rozwoju Regionalnego Uniwersytetu Wrocławskiego, 79-90.

Rachwał, T., Wiedermann, K., Kilar, W. (2009). Rola przemysłu w gospodarce układów regionalnych Unii Europejskiej. Prace Komisji Geografii Przemystu Polskiego Towarzystwa Geograficznego, $14,31-42$.

Raczyk, A., Dobrowolska-Kaniewska, H. (2009). Kształtowanie struktur przestrzennych sektora przemysłu i usług według poziomów techniki na przykładzie województwa dolnośląskiego. Prace Komisji Geografii Przemystu Polskiego Towarzystwa Geograficznego, 13, 42-55.

Reśko, D. (2003). Kształtowanie się przedsiębiorstwa usługowo-handlowego Profex Consulting. Prace Komisji Geografii Przemystu Polskiego Towarzystwa Geograficznego, 4, 141-146.

Rochnowski, H. (2000). Niektóre kierunki, cele i uwarunkowania przemysłu Polski w okresie transformacji. Prace Komisji Geografii Przemystu Polskiego Towarzystwa Geograficznego, 1, 45-53.

Rydz E., Jażewicz, I. (1994). Przemiany struktur przestrzenno-gałęziowych przemysłu województwa słupskiego w zmieniających się warunkach gospodarowania. W: Z. Zioło (red.), Zachowania przestrzenne przemystu $w$ zmieniajacych się warunkach gospodarowania. Kraków- Warszawa: Instytut Geografii Wyższej Szkoły Pedagogicznej w Krakowie, Komisja Geografii Przemysłu PTG, 132-144.

Rydz, E., Barańska, P. (2000). Wybrane problemy przemysłu mleczarskiego województwa słupskiego w latach 1990-1996. Prace Komisji Geografii Przemystu Polskiego Towarzystwa Geograficznego, $1,55-66$. 
Rydz, E., Jażewicz, I. (2002). Przemiany strukturalne przemysłu na przykładzie małych miast Pomorza Środkowego. Prace Komisji Geografii Przemystu Polskiego Towarzystwa Geograficznego, 3, 71-86.

Rydz, E., Szymańska, W. (2003). Funkcjonowanie zakładów przemysłu obuwniczego regionu słupskiego w zmieniających się warunkach gospodarowania. Prace Komisji Geografii Przemystu Polskiego Towarzystwa Geograficznego, 4, 43-56.

Sala, S. (2003). Wybrane cechy działalności korporacji transnarodowych i ich implikacje dla Polski. Prace Komisji Geografii Przemystu Polskiego Towarzystwa Geograficznego, 6, 101-108.

Sala, S. (2006). Polskie firmy na tle zagranicznych korporacji w dobie globalizacji. Prace Komisji Geografii Przemystu Polskiego Towarzystwa Geograficznego, 9, 170-180.

Smętkowski, M. (2008). Rola specjalnych stref ekonomicznych w kształtowaniu struktury przestrzennej przemysłu w Polsce. Prace Komisji Geografii Przemystu Polskiego Towarzystwa Geograficznego, 10, 204-216.

Stryjakiewicz, T. (1994). Próba analizy i oceny procesów transformacji przemysłu w Polsce w świetle postfordowskiego modelu elastycznej produkcji i teorii regulacji. In: Z. Zioło (ed.), Zachowania przestrzenne przemystu $w$ zmieniających się warunkach gospodarowania. Kraków-Warszawa: Instytut Geografii Wyższej Szkoły Pedagogicznej w Krakowie, Komisja Geografii Przemysłu PTG, 48-66.

Stryjakiewicz, T. (1999). Adaptacja przestrzenna przemyslu $w$ Polsce $w$ warunkach transformacji. Poznań: Wydawnictwo Naukowe Uniwersytetu im. Adama Mickiewicza.

Stryjakiewicz, T. (2002). Orientacje teoretyczno-metodologiczne w geografii przemysłu a transformacja gospodarki. Prace Komisji Geografii Przemystu Polskiego Towarzystwa Geograficznego, 3, $13-27$.

Stryjakiewicz, T. (2010). Przemiany w geografii przemysłu. Prace Komisji Geografii Przemystu Polskiego Towarzystwa Geograficznego, 15, 30-44.

Szmielińska-Pietraszek, P., Szymańska, W. (2008). Przestrzeń przemysłowa Szczecinka i Lęborka w układach regionalnych województwa pomorskiego i zachodniopomorskiego. Prace Komisji Geografii Przemystu Polskiego Towarzystwa Geograficznego, 10, 35-44.

Szmytkowska, M. (2004). Przemysł w mieście poprzemysłowym. Przykład Gdyni. Prace Komisji Geografii Przemystu Polskiego Towarzystwa Geograficznego, 7, 43-52.

Szymańska, A. (2011). Implementacja systemu TQM w podnoszeniu pozycji konkurencyjnej przedsiębiorstwa przemysłowego. Prace Komisji Geografii Przemystu Polskiego Towarzystwa Geograficznego, 17, 243-260.

Szymańska, A. (2012). Innowacyjność produktowa przedsiębiorstw produkcyjnych a preferencje konsumentów. Prace Komisji Geografii Przemystu Polskiego Towarzystwa Geograficznego, 20, $147-161$.

Śleszyński, P. (2010). Powiązania organizacyjne i właścicielskie przedsiębiorstw przemysłowych i usługowych w Polsce oraz ich znaczenie dla rozwoju regionalnego. Prace Komisji Geografii Przemystu Polskiego Towarzystwa Geograficznego, 15, 117-129.

Świdurska, A. (2009). Kształtowanie się wysokiej techniki w Polsce. Prace Komisji Geografii Przemystu Polskiego Towarzystwa Geograficznego, 13, 56-67.

Świdurska, A. (2010). Efektywność rozwoju przedsiębiorstw produkcyjnych wysokiej techniki w Polsce. Prace Komisji Geografii Przemystu Polskiego Towarzystwa Geograficznego, 15, 197 208.

Tkocz, M. (2001). Restrukturyzacja przemysłu regionu tradycyjnego. Prace Naukowe Uniwersytetu Ślaskiego w Katowicach, 1998. Katowice: Wydawnictwo Uniwersytetu Śląskiego.

Tkocz, M. (2003). Przejawy procesu globalizacji w przemyśle województwa śląskiego. Prace Komisji Geografii Przemystu Polskiego Towarzystwa Geograficznego, 6, 67-76.

Tkocz, M. (2006). Efekty restrukturyzacji górnictwa węgla kamiennego w Polsce. Prace Komisji Geografii Przemystu Polskiego Towarzystwa Geograficznego, 9, 28-39. 
Tkocz, M., Heder, A. (2012). Działalność innowacyjna upadającej branży przemysłowej na przykładzie górnictwa węgla kamiennego. Prace Komisji Geografii Przemystu Polskiego Towarzystwa Geograficznego, 20, 134-146.

Tkocz, M., Sobala, P. (2006). Kapitał zagraniczny w przemianach gospodarczych tradycyjnego ośrodka przemysłowego na przykładzie Chorzowa. Prace Komisji Geografii Przemystu Polskiego Towarzystwa Geograficznego, 8, 74-79.

Tobolska, A. (2004). Procesy koncentracji gospodarczej dużych przedsiębiorstw przemysłowych Poznania. Prace Komisji Geografii Przemystu Polskiego Towarzystwa Geograficznego, 7, 31-42.

Tobolska, A. (2006). Nowy model organizacji i funkcjonowania starych przedsiębiorstw przemysłowych. Prace Komisji Geografii Przemystu Polskiego Towarzystwa Geograficznego, 9, 83-97.

Tobolska, A., Matykowski, R. (2006). Działalność przemysłowa w warunkach wzrastającej internacjonalizacji i globalizacji na przykładzie wybranych produktów. Prace Komisji Geografii Przemysłu Polskiego Towarzystwa Geograficznego, 8, 47-59.

Wdowicka, M. (2002). Wykształcanie się nowych obszarów przemysłowych w strefie podmiejskiej Poznania. Prace Komisji Geografii Przemystu Polskiego Towarzystwa Geograficznego, 3, 115122.

Wiedermann, A. (2010). Funkcje przemysłu w potencjale społeczno-ekonomicznym centrów rozwoju województwa śląskiego. Prace Komisji Geografii Przemystu Polskiego Towarzystwa Geograficznego, 15, 142-155.

Wiedermann, K. (2008). Czynniki i skutki rozwoju przemysłu motoryzacyjnego na terenie województwa śląskiego. Prace Komisji Geografii Przemystu Polskiego Towarzystwa Geograficznego, 10, 93-108.

Wiedermann, K., Trojak, A. (2009). Specjalne strefy ekonomiczne i strefy przemysłowe w kształtowaniu rozwoju gospodarczego regionów na przykładzie Polski i Czech. Prace Komisji Geografii Przemystu Polskiego Towarzystwa Geograficznego, 12, 133-144.

Wieloński, A. (1998). Od industrializacji do reindustrializacji. Warszawa: Uniwersytet Warszawski, Wydział Geografii i Studiów Regionalnych.

Wieloński, A. (2006). Przemysł Nowej Gospodarki. Prace Komisji Geografii Przemystu Polskiego Towarzystwa Geograficznego, 6, 21-26.

Wieloński, A. (2009). Renesans polskiego hutnictwa żelaza i stali. Prace Komisji Geografii Przemystu Polskiego Towarzystwa Geograficznego, 12, 59-62.

Wieloński, A. (2010). Wielkość i struktura eksportu miarą konkurencyjności polskiego przemysłu. Prace Komisji Geografii Przemystu Polskiego Towarzystwa Geograficznego, 15, 99-104.

Wieloński, A., Bazydło, A. (2003). Proces integracji z Unią Europejską a przemiany strukturalne w przemyśle Polski. Prace Komisji Geografii Przemysłu Polskiego Towarzystwa Geograficznego, $4,19-24$.

Wieloński, A., Szmigiel, K. (2006). Regionalne strategie innowacji jako czynnik aktywizacji polskiej przestrzeni przemysłowej. Prace Komisji Geografii Przemysłu Polskiego Towarzystwa Geograficznego, 9, 20-27.

Zioło, Z., Borowiec, M., Kilar, W. (2007). Problematyka XXII. Ogólnopolskiej Konferencji Naukowej nt. Problemy metodologiczne geografii przemystu. Warszawa-Kraków: Komisja Geografii Przemysłu PTG, Zakład Przedsiębiorczości i Gospodarki Przestrzennej IG AP, 3-13.

Zioło, Z. (1988). Funkcjonowanie i rozwój przedsiębiorstwa przemysłowego w przestrzeni geograficznej. In: Z. Zioło (ed.), Zakład przemysłowy w akademickim kształceniu nauczycieli geografii. Materiały i Sprawozdania COMSN, 16, Kraków: Wydawawnictwo Naukowe WSP.

Zioło, Z. (1994). Zmiany otoczenia przedsiębiorstw przemysłowych w nowych warunkach gospodarowania. In: Z. Zioło (ed.), Funkcjonowanie przedsiębiorstw przemystowych w zmieniajacych się warunkach gospodarowania. Materiały i Sprawozdania COMSN, 29, Kraków: Wydawawnictwo Naukowe WSP. 
Zioło, Z. (1997). Miejsce struktury przestrzennej przemysłu w przestrzeni geograficznej. In:A. Jackowski, B. Domański (eds.), Geografia, Człowiek, Gospodarka. Profesorowi Bronisławowi Kortusowi w 70. rocznicę urodzin. Kraków: Wydawnictwo Uniwersytetu Jagiellońskiego.

Zioło, Z. (2000). Problemy integracji międzynarodowej przemysłu w procesie zmian systemu gospodarowania. Prace Komisji Geografii Przemystu Polskiego Towarzystwa Geograficznego, 1, 13-21.

Zioło, Z. (2001). Współczesne tendencje rozwoju przemysłu i ich problematyka badawcza. Prace Komisji Geografii Przemysłu Polskiego Towarzystwa Geograficznego, 2, 9-20.

Zioło, Z. (2002). Struktura branżowa i koncentracja przestrzenna wiodących światowych firm przemysłowych. Prace Komisji Geografii Przemystu Polskiego Towarzystwa Geograficznego, 3, 29-41.

Zioło, Z. (2003). Kształtowanie się przedsiębiorstw przemysłowych w procesie globalizacji. Prace Komisji Geografii Przemystu Polskiego Towarzystwa Geograficznego, 6, 9-20.

Zioło, Z. (2004). Kształtowanie się firm informatycznych jako nowych elementów struktury przestrzennej przemysłu. Prace Komisji Geografii Przemystu Polskiego Towarzystwa Geograficznego, 7, 97-106.

Zioło, Z. (2006a). Problematyka badawcza efektów restrukturyzacji polskiej przestrzeni przemysłowej. Prace Komisji Geografii Przemystu Polskiego Towarzystwa Geograficznego, 9, 11-19.

Zioło, Z. (2006b). Zróżnicowanie światowej przestrzeni przemysłowej w świetle koncentracji siedzib zarządów wiodących korporacji. Prace Komisji Geografii Przemystu Polskiego Towarzystwa Geograficznego, 8, 9-26.

Zioło, Z. (2008a). Problemy badawcze struktury przestrzennej przemysłu. Prace Komisji Geografii Przemystu Polskiego Towarzystwa Geograficznego, 11, 9-25.

Zioło, Z. (2008b). Procesy transformacji przemysłowych układów przestrzennych na tle zmieniającego się otoczenia. Prace Komisji Geografii Przemystu Polskiego Towarzystwa Geograficznego, 10, $11-22$.

Zioło, Z. (2009a). Procesy kształtowania się światowych korporacji i ich wpływ na otoczenie. Prace Komisji Geografii Przemystu Polskiego Towarzystwa Geograficznego, 12, 11-32.

Zioło, Z. (2009b). Rola przemysłu w procesie kształtowania społeczeństwa informacyjnego. Prace Komisji Geografii Przemystu Polskiego Towarzystwa Geograficznego, 13, 11-20.

Zioło, Z. (2013a). Rola przemysłu i usług w kształtowaniu gospodarki opartej na wiedzy. Prace Komisji Geografii Przemystu Polskiego Towarzystwa Geograficznego, 21, 11-30.

Zioło, Z. (2013b). Uwarunkowania kształtowania się procesów transformacji przemysłu i usług. Prace Komisji Geografii Przemystu Polskiego Towarzystwa Geograficznego, 15, 45-60.

Wiesława Gierańczyk, Ph.D., Jagiellonian College, Toruń, Poland. The author of about 80 scientific publications. Her research interests revolve around industrial geography, innovation, education, entrepreneurship and regional typologies.

\section{Adres/address:}

Jagiellonian College in Toruń

ul. Młodzieżowa 29, 87-100 Toruń, Poland

e-mail:w.gieranczyk@tsw.edu.pl 